Tropical Journal of Pharmaceutical Research May 2016; 15 (5): 895-903

ISSN: $1596-5996$ (print); 1596-9827 (electronic)

(C) Pharmacotherapy Group, Faculty of Pharmacy, University of Benin, Benin City, 300001 Nigeria.

All rights reserved.

Available online at http://www.tjpr.org

Original Research Article

http://dx.doi.org/10.4314/tjpr.v15i5.1

\title{
Development of paclitaxel-loaded liposomal systems with anti-her2 antibody for targeted therapy
}

\author{
Gülay Büyükköroğlu ${ }^{1}$, Behiye Şenel ${ }^{1}$, Ebru Başaran ${ }^{2}$ and Seval Gezgin ${ }^{3}$ \\ ${ }^{1}$ Department of Pharmaceutical Biotechnology, ${ }^{2}$ Department of Pharmaceutical Technology, ${ }^{3}$ Advanced Technologies Research \\ Center (ITAB), Department of Biotechnology, Anadolu University, Eskisehir, Turkey
}

*For correspondence: Email: gbuyukko@anadolu.edu.tr; Tel: +902223350580/3726, +905326338225

\begin{abstract}
Purpose: To develop liposome formulations containing monoclonal antibody anti-HER2 (MabHer2), and Paclitaxel (PTX).

Methods: Seven different liposomal systems containing PTX, or MabHer2 or a combination of PTX and MabHer2 were made using lipid film hydration technique and sonication. The effects of liposome preparation conditions and extraction methods on antibody structure were investigated by polyacrylamide gel electrophoresis and 3-(4,5-dimethylthiazol-2-yl)-2,5-diphenyltetrazolium bromide (MTT) assay. The characteristics of the liposomes were determined by a zetasizer, while drug-loading efficiency was evaluated by high-performance liquid chromatography. The cytotoxic effect of the liposome formulations was evaluated on MDA-MB-453 (HER2+) and MCF-7 (HER2-) breast cancer cell lines by MTT assay.

Results: The antibody was not significantly affected by the stress conditions and the method of extraction. The particle size of liposomes was $<200 \mathrm{~nm}$ while the amount of incorporated PTX was 97.6 $\%$ for liposome without cationic agent and $98.2 \%$ for those with cationic agent. Recovery of MabHer2 was $94.38 \%$ after extraction. Combined PTX/MabHer2 liposome was more toxic on HER2 overexpressing positive MDA-MB-453 cell line than PTX-loaded liposomes and MabHer2. MabHer2 and combined PTX/MabHer2 liposomes showed no toxic effects on HER2 overexpressing negative MCF-7 cells relative to cationic $P T X$-loaded liposomes.

Conclusions: This results obtained show that PTX can be encapsulated successfully into liposomal systems and that owing to Her2 specific antibody, these systems can be delivered directly to the target cell.
\end{abstract}

Keywords: Cancer, Anti-her2 antibody, Liposome, Paclitaxel, Targeted therapy, Cell culture

Tropical Journal of Pharmaceutical Research is indexed by Science Citation Index (SciSearch), Scopus, International Pharmaceutical Abstract, Chemical Abstracts, Embase, Index Copernicus, EBSCO, African Index Medicus, JournalSeek, Journal Citation Reports/Science Edition, Directory of Open Access Journals (DOAJ), African Journal Online, Bioline International, Open-J-Gate and Pharmacy Abstracts

\section{INTRODUCTION}

Majority of the drugs used in cancer treatment have cytotoxic effects on both cancerous and normal cells. For this reason, conventional approaches for treatment of cancer and viral diseases are now giving way to smart drug delivery systems that minimize toxicity to normal cells, remain in circulation for longer periods and target specific cells [1].

PTX is one of the most important chemotherapeutic agents, usually administered via intravenous (IV) infusion. Due to its hydrophobic properties, it is usually formulated as 1:1 mixture with Cremophor EL or polyetoxy castor oil or alcohol. Cremophor EL is 
incompatible with polyvinyl alcohol (PVA) and has toxic properties. These shortcomings limit the stability of infusion formulations, and render them toxic in clinical applications.

PTX does not differentiate between cancerous and normal cells. Thus it has been suggested that localized and targeted PTX carrier systems need to be developed in order to reduce its toxicity and side effects [2]. Recent studies have shown that liposomal formulations of PTX and its derivatives were very effective in pre-clinical trials [3].

There are two major problems related with utilization of nanoparticles as drug carriers. First, nanoparticles cannot maintain their integrity during in vivo applications, so that the transported drug is released into circulation before it reaches the targeted site. Second, nanoparticles are captured by the cells of the reticuloendothelial system (RES) before reaching the targeted site [4]. To overcome these problems, cell-specific targeting studies have been conducted by binding antibodies to drug carrying vesicular systems [5].

Monoclonal antibodies directed against various target molecules are the most effective tools in cancer treatment today. High specificity and favorable toxicity profiles have placed these agents among standard treatment protocols despite their high costs [6]. Cancer cells and healthy cells have different anatomies and protein expressions [7]. The former often overexpress peptides, hormones and receptors for endocytosis of essential nutrients [8]. These receptors can be exploited for active and specific targeting for colloidal drug carriers.

Humanized monoclonal antibody against HER2/ErbB-2 (human epidermal growth factor receptor $2 / \mathrm{Neu}$ ), known as herceptin/trastzumab is a chemo-sensitizer widely used as an antitumor agent in breast and ovary cancer [9].

The purpose of this study was to develop liposome formulations containing anti-HER2 antibody (MabHer2) and chemotherapeutic agent PTX.

\section{EXPERIMENTAL}

\section{Materials}

Phospholipon $85 \mathrm{G}^{\circledR}$ was used as a phospholipid and were purchased from Phospholipid $\mathrm{GmbH}$ (Köln, Germany). Anti-HER2 Antibody, Paclitaxel (from Taxus yannanensis, powder), were provided by Sigma-Aldrich (Hong Kong, China). While dichloromethane was obtained from Sigma-Aldrich (Steinheim, Germany), dimethylsulfoxide (DMSO) was from Applichem (Darmstadt, Germany). Octadecylamine were purchased from Fluca (Darmstadt, Germany).

\section{Preparation of liposomes}

Liposomes were prepared using the modified method of lipid film hydration technique with sonication [10]. Phospholipon $85 \mathrm{G}^{\circledR}(40 \mathrm{mg})$ was dissolved in $1 \mathrm{~mL}$ dichloromethane (DCM) which was used as an organic phase in a round bottom glass flask. While rotating in Rotavapor (Buchi R205 Rotavapor, Switzerland) at 90-100 rpm on $33{ }^{\circ} \mathrm{C}$ water bath, the organic solvent was removed under 250 mbar pressure, to form a lipid film layer on the inside surface of $5 \mathrm{~mL}$ the flask. After formation of lipid film, $2 \mathrm{~mL}$ aqueous phase $(0.9 \% \mathrm{NaCl}, \mathrm{pH} 7.4)$ was added, and the mixture was sonicated for $1.5 \mathrm{~min}$ at $20 \%$ power using a sonicator (Sonics, USA) [11]. In the preparation of cationic liposome, octadecylamine (OCT) dissolved in organic phase was used as a cationic agent. Placebo liposome formulation was prepared without the addition of PTX.

In the case of PTX loaded liposomes, OCT and PTX were dissolved in DCM as a lipid phase, and the liposomes were prepared as described above. To adsorb/load MabHer2 to formulations, the antibody was dispersed in the aqueous phase at predetermined concentration and added to the glass flask that included lipid(s) or lipid(s)/PTX mixture film, and sonicated [11]. Codes of the formulations and their proportions are given in Table 1.

\section{Evaluation of particle size and zeta potential}

Mean diameter of the bulk population and the particle distribution via the polydispersity index (PI) and zeta potentials of liposomes were analyzed by a Zetasizer NanoZS (Malvern Instruments, UK). Distilled water with a conductivity value of $50 \mu \mathrm{S} / \mathrm{cm}$ was adjusted using sodium chloride $(0.1 \mathrm{~N})$ at $\mathrm{pH} 7.4$ and used in zeta potential analyses. Electrostatic mobility was converted to zeta potential using HelmholtzSmoluchowski equation. For the analyses constant amount $(30 \mu \mathrm{L})$ of liposomes were dispersed in $1 \mathrm{~mL}$ of the distilled water and particle size, PI and zeta potentials were recorded $(n=3)$.

\section{Determination of sonication effect on MabHer2}

The primary structure of the antibodies exposed 
Table 1: Codes, compositions, mean particle sizes, particle sizes distributions and zeta potentials of the liposomes

\begin{tabular}{|c|c|c|c|c|c|c|c|}
\hline Code & $\begin{array}{l}\text { Phospholipon } \\
85 \mathrm{G}^{\circledR}(\mathrm{mg} / 2 \mathrm{~mL})\end{array}$ & $\begin{array}{c}\text { OCT } \\
(\mathrm{mg} / 2 \mathrm{~mL})\end{array}$ & $\begin{array}{c}\text { PTX } \\
(\mathrm{mg} / 2 \mathrm{~mL})\end{array}$ & $\begin{array}{l}\text { MabHer2 } \\
(\mathrm{mg} / 2 \mathrm{~mL})\end{array}$ & PS (nm) & PI & $\mathrm{ZP}(\mathrm{mV})$ \\
\hline$\overline{\mathrm{LP}}$ & 40 & - & - & - & $84.55 \pm 5.30$ & $0.277 \pm 0.078$ & $-36.90 \pm 0.33$ \\
\hline LPO & 40 & 1.2 & - & - & $47.11 \pm 3.72$ & $0.567 \pm 0.053$ & $31.20 \pm 0.79$ \\
\hline $\mathrm{LPOH}$ & 40 & 1.2 & - & 1 & $179.01 \pm 7.35$ & $0.493 \pm 0.672$ & $13.45 \pm 0.03$ \\
\hline LPX & 40 & - & 3 & - & $198.21 \pm 5.61$ & $0.528 \pm 0.712$ & $-26.03 \pm 0.98$ \\
\hline LPXH & 40 & - & 3 & 1 & $189.32 \pm 6.32$ & $0.407 \pm 0.820$ & $-24.70 \pm 1.03$ \\
\hline LPXO & 40 & 1.2 & 3 & - & $172.76 \pm 2.43$ & $0.720 \pm 0.232$ & $4.71 \pm 0.72$ \\
\hline $\mathrm{LPXOH}$ & 40 & 1.2 & 3 & 1 & $165.35 \pm 6.22$ & $0.603 \pm 1.023$ & $5.35 \pm 1.72$ \\
\hline
\end{tabular}

Experiments were carried out in triplicates. PS; Particle size, Pl; Polydispersity Index, ZP; Zeta potential and SE; Standard error

to stress by sonication for different periods was determined using SDS-PAGE method [12].

MabHer2 was dispersed in aqueous phase (0.9 $\% \mathrm{NaCl}, \mathrm{pH} 7.4$ ) at a formulation concentration of $1 \mathrm{mg} / \mathrm{mL}$, in a flask immersed in a temperaturecontrolled $\left(2^{\circ} \mathrm{C}\right)$ water bath. The dispersions were sonicated for $10 \mathrm{~min}$ at $20 \%$ power, and the procedure was paused to obtain $20 \mu \mathrm{L}$ sample once every other minute. After the 10th minute, the procedure was paused once every 5 min to obtain 2 more samples at the end of the 20th minute. Each sample was added to $20 \mu \mathrm{L}$ loading buffer (Laemmli $2 X$ concentrate, SigmaAldrich, USA), and then heated at $90{ }^{\circ} \mathrm{C}$ for 4 $\min$.

The $20 \mu \mathrm{L}$ sample obtained from the MabHer2 dispersion prior to application of sonication procedure served as positive control. A $12 \%$ polyacrylamide gel was prepared and the samples were applied on the gel in aliquots of 40 $\mu \mathrm{L}$. SDS-PAGE was performed on a vertical electrophoresis system (Cleaver Scientific, UK ) at a constant voltage of $150 \mathrm{~V}$ for about $3 \mathrm{~h}$. The gel was thereafter stained with coomassie blue and then de-stained in distilled water overnight. Images were obtained using Kodak Image Station 440CF (USA).

\section{MabHer2 extraction and quantitation}

Extraction method was used for isolation and quantitative determination of MabHer2 from $\mathrm{LPXH}$ and $\mathrm{LPXOH}$ formulations. A sample of each formulation $(400 \mu \mathrm{L})$ was put in a micro tube, and $1 \mathrm{~mL}$ DCM was slowly added down the side of the tube. The tube was slowly turned upside down to allow the lipid and PTX to dissolve in the organic solvent, and then centrifuged at $8000 \mathrm{rpm}$ for $5 \mathrm{~min}$. The aqueous phase that contained the antibody was carefully removed, and its concentration was determined using nano-drop spectrophotometer (BioSpecNano, Shimadzu, USA) by reading absorbance at $280 \mathrm{~nm}$. Antibody extracted from LPXH was designated exLPXmab, and while that extracted from LPXOH was designated exLPXOHmab.

\section{Evaluation of effect of extraction method on MabHer2}

The effect of extraction method used on MabHer2 was determined with SDS-PAGE method. $10 \mu \mathrm{L}$ of the extracted MabHer2s were mixed with $10 \mu \mathrm{L}$ loading tampon, and loaded on to polyacrylamide gel as described above.

\section{Morphological characterization}

Morphological evaluation of nanoparticles is possible using scanning electron microscopy (SEM) and transmission electron microscopy (TEM) [13]. The morphological examination of the formulations was done using Carl Zeiss Microscopy (SUPRA 50VP model, Oberkochen, Germany).

Liposomes (loaded with PTX or free) were dropped on the sampling chamber, and were allowed to dry at room-temperature. They were then coated to a thickness of approximately $100 \AA$ with gold, prior to the analyses.

\section{Quantitation of PTX}

High Performance Liquid Chromatography (HPLC) (20 A; Shimadzu Corporation, Tokyo, Japan) was used for quantitation of loaded PTX. Shimadzu Shim-Pack CLC-ODS column with a diameter of $6.0 \mathrm{~mm}$ and length of $15.0 \mathrm{~cm}$ was used. The mobile phase was acetonitrile: distilled water (50: $50 \mathrm{v} / \mathrm{v}$ ) mixture, at a flow rate of $1 \mathrm{~mL} / \mathrm{min}$. For each sample, $20 \mu \mathrm{L}$ was analyzed at $227 \mathrm{~nm}$. Column temperature was set to $30{ }^{\circ} \mathrm{C}$. Validation studies were performed for the reliability of data [14].

In order to determine PTX content of the formulations, $500 \mu \mathrm{L}$ of the formulation was mixed with $1.5 \mathrm{~mL}$ methanol and the mixture was filtered through a $0.22 \mu \mathrm{m}$ pore size polyamide membrane filter. The filtrate $(500 \mu \mathrm{L})$ was mixed 
with $500 \mu \mathrm{L}$ mobile phase and the HPLC analyses were performed. PTX content of the formulations was calculated according to Eq 1 .

$E(\%)=\{(\mathrm{Di} / \mathrm{Dt})\} 100$

where $\mathrm{Di}$ and $\mathrm{Dt}$ are the incorporated and total drug, respectively.

\section{Evaluation of cytotoxicity}

Colorimetric $\quad 3-(4,5-$ dimethylthiazol-2-yl)-2,5diphenyltetrazolium bromide (MTT) method was used for the quantitative determination of cytotoxicity of the formulations on MDA-MB-453 (HER2+) and MCF-7 (HER2-) breast cancer cells. The cells $\left(2 \times 10^{4}\right)$ were seeded in a 96well plate (Greiner, Sigma-Aldrich), and incubated at $37{ }^{\circ} \mathrm{C}$ for $24 \mathrm{~h}$ in a humidified atmosphere containing $5 \% \mathrm{CO}_{2}$.

The supernatant of each well was replaced with different concentrations of formulations, and the plates were incubated at $37{ }^{\circ} \mathrm{C}$ for $48 \mathrm{~h}$, after which the supernatants were replaced with $20 \mu \mathrm{L}$ of MTT dye (Greiner, Sigma-Aldrich, diluted with PBS for $5 \mathrm{mg} / \mathrm{mL}$ concentration) solution. The plates were incubated for $4 \mathrm{~h}$ under the same conditions earlier mentioned.

Then $200 \mu \mathrm{L}$ spectrophotometric DMSO was then added to each well to dissolve the resultant formazan crystals. After $30 \mathrm{~min}$ of incubation, absorbance of the plates were measured at 570 $\mathrm{nm}$ using a spectrometric microplate reader (Perkin Elmer Victor X5, England) [15].

\section{Evaluation of effect of extraction method on MabHer2 activity}

In order to determine the effects of the extraction method on the antibody activity, different concentrations $(1,1.25,1.5,1.75,2$ and 2.5 $\mu \mathrm{g} / 100 \mu \mathrm{L}$ ) of MabHer2, exLPXHmab and exLPXOHmab were applied to MDA-MB-453 (HER2+) cell lines, and their effectiveness was determined via MTT.

\section{RESULTS}

\section{Characterization studies of liposomes}

The mean diameter, size distribution and zeta potential of the various liposomes are shown in Table 1. As the values show, incorporation of PTX into liposomes increased the size and decreased zeta potential of the liposomes. SEM images also confirm that particles were in the nanometer range with spherical structures (Figure 1).

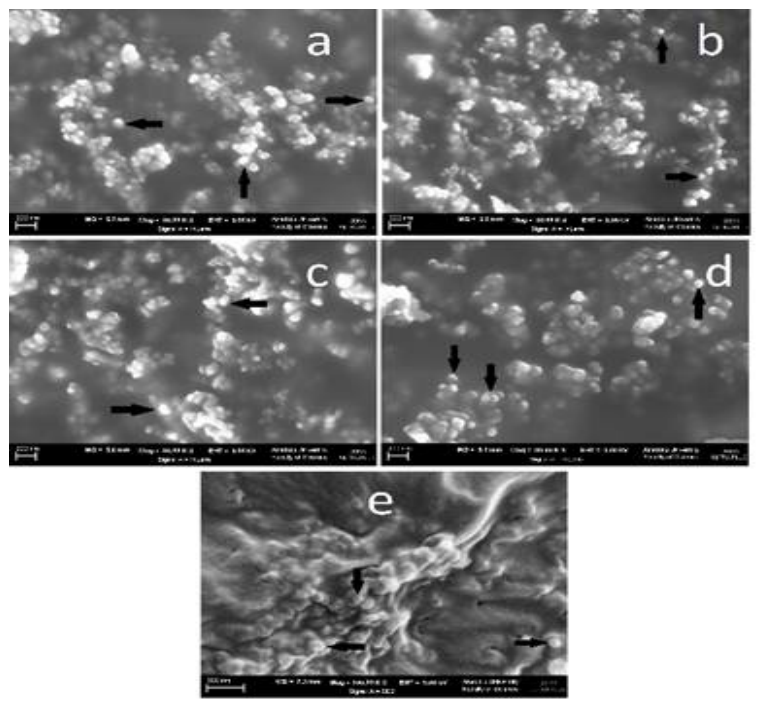

Figure 1: SEM images of LPO (a), LPOH (b), LPX (c),LPXO (d) and LPXOH (e)

\section{Efficacy of MabHer2s}

As Figure 2 - Figure 3 illustrates, no structural changes in antibodies between the native and the ultrasonicated MabHer2 solutions was found. Similarly, all bands of MabHer2s were in the same line and at similar concentrations. The concentration of the antibody obtained after extraction was $0.4719 \pm 0.00695 \mu \mathrm{g} / \mu \mathrm{L}$ with the recovery rate of $94.38 \%$.

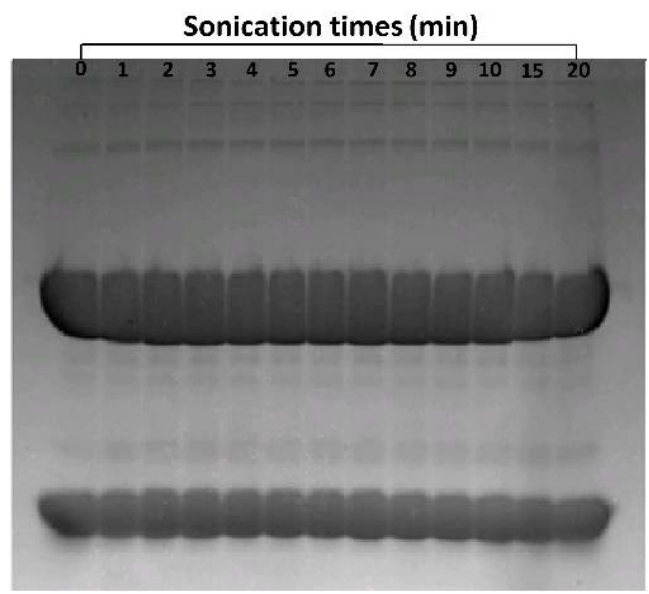

Figure 2: SDS-PAGE gel image of native and 1-10, 15 and 20 minutes sonicated MabHer2 solutions

\section{PTX content}

Linearity was evaluated within the $1-10 \mu \mathrm{g} \cdot \mathrm{mL}^{-1}$ range and the regression equation was determined as $y=19289 x-1503\left(r^{2}=0.9999\right)$. The precision data were 1.5 and $2.0 \%$ for repeatability and reproducibility respectively. 
Accuracy of the method was calculated as 100.4 $\pm 0.5 \%$. Limit of detection (LOD) was found 21.0 $\pm 0.4 \mathrm{ng} \cdot \mathrm{mL}^{-1}$, while limit of quantitation (LOQ) was $62 \pm 0.8 \mathrm{ng} \cdot \mathrm{mL}^{-1}$. The level of incorporated PTX in the LPX and LPXO formulations were calculated as $97.6 \pm 0.3$ and $98.2 \pm 0.7 \%$, respectively with Eq 1 .

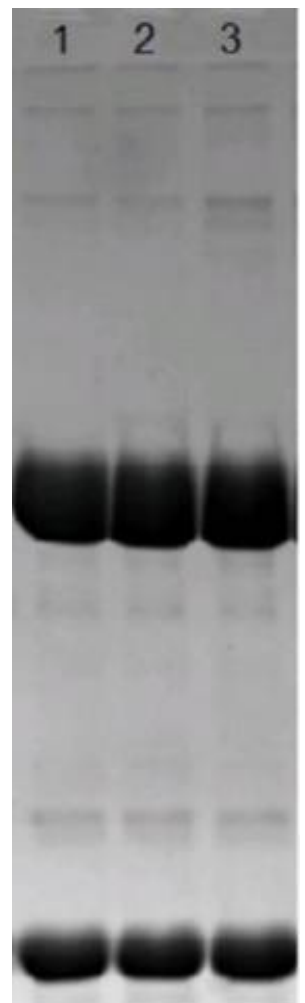

Figure 3: SDS-PAGE gel image of native (1), extracted from LPXH (2) and extracted LPXOH (3) MabHer2 solutions

\section{Cell viability}

The toxic effects of MabHer2 extracted from formulations (exLPXmab and exLPXOHmab) and native MabHer2 on MDA-MB-453 (HER2+) cell lines after $48 \mathrm{~h}$ were evaluated and the results are shown in Figure 4. The toxic values of Mabs exposed to cells at concentrations present in formulations were similar to each other $\left(\mathrm{IC}_{50}, 2\right.$ $\mu \mathrm{L} / 100 \mu \mathrm{L})$.

The toxicities of MabHer2 antibody, placebo liposome (LP and LPO), PTX-loaded and PTX/MabHer2-loaded formulations on both cell lines are shown in Figures 5 and 6.

\section{DISCUSSION}

High-energy input such as elevated production temperature, high stirring rate, long emulsification time, and/or strong ultrasound power is required to breakdown the droplets into nanometer range [16]. However, it is known that the long sonication time applied for decreasing particle size and polydispersity index causes metal contamination [17]. In this study, particle sizes of LP and LPO formulations which did not contain PTX and MabHer2 were 84.55 and 47.11 $\mathrm{nm}$, respectively. As should be expected, increases in the particle sizes of LPX and LPXO were observed after addition of PTX (198 and $172 \mathrm{~nm}$ ). Formulations obtained via addition of MabHer2 alone or in combination with PTX

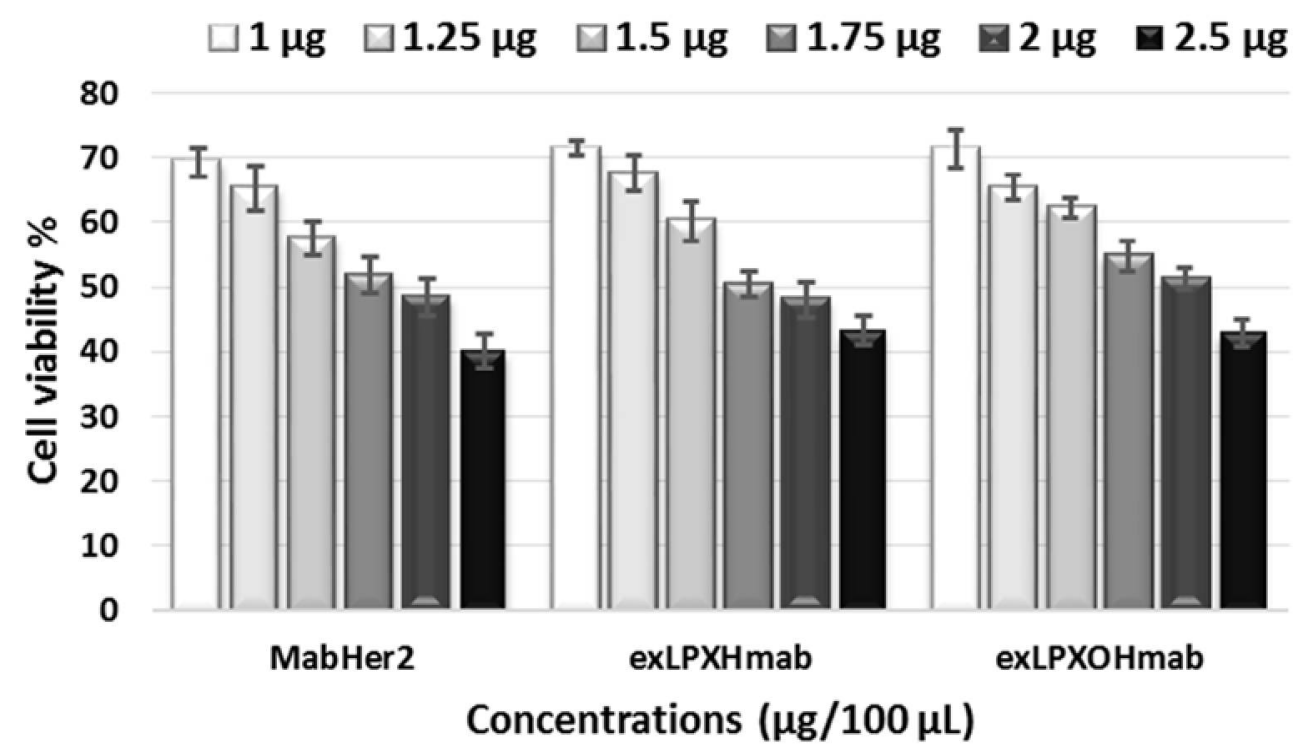

Figure 4: Viability of MDA-MB-453 cells after being treated with native and extracted MabHer2 solutions. Each condition was tested in eight replicates for $48 \mathrm{~h}$ 


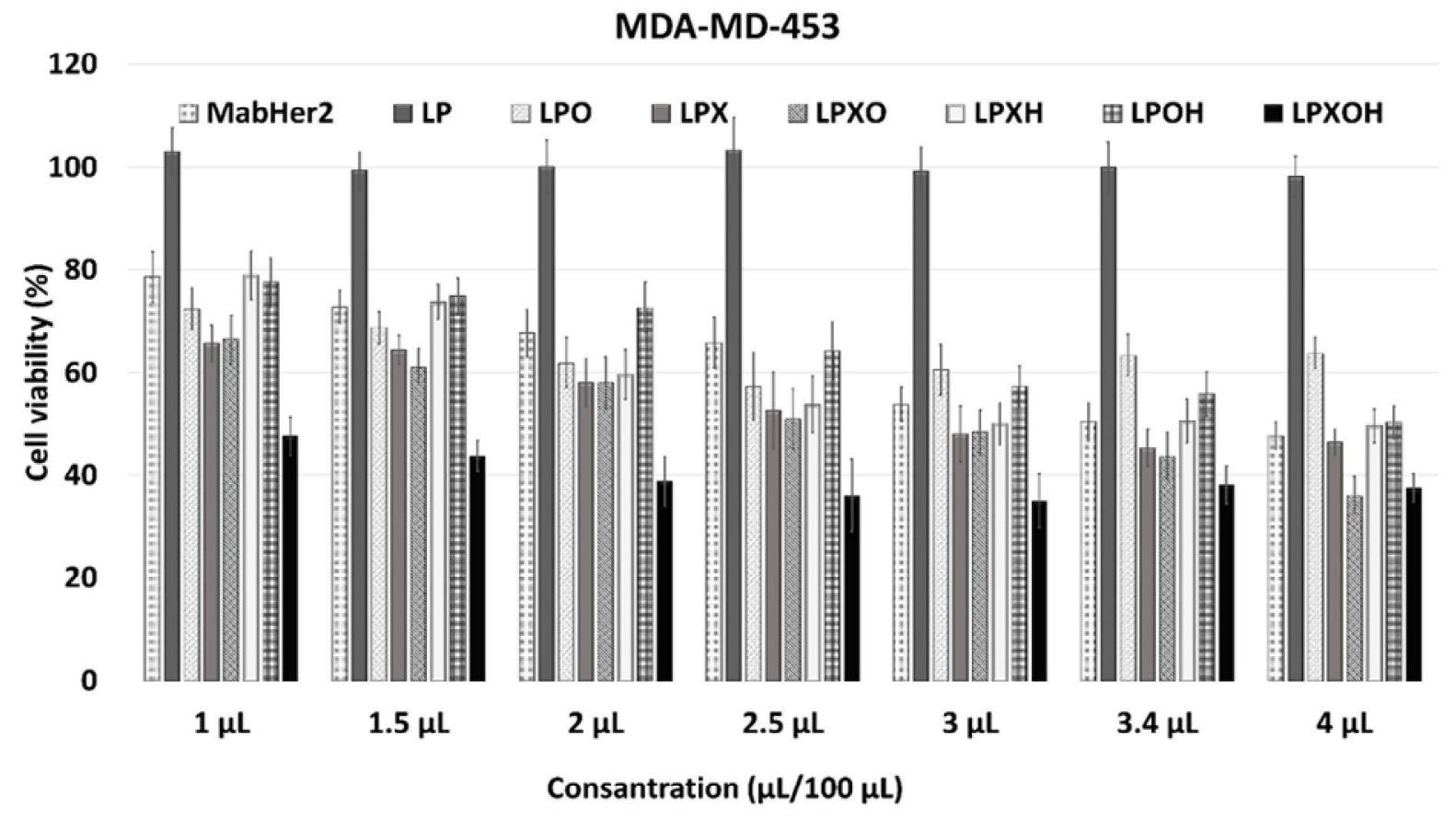

Figure 5: Viability of MDA-MB-453 cells after being treated with MabHer2 solution and liposomes. Each condition was tested in eight replicates for $48 \mathrm{~h}$

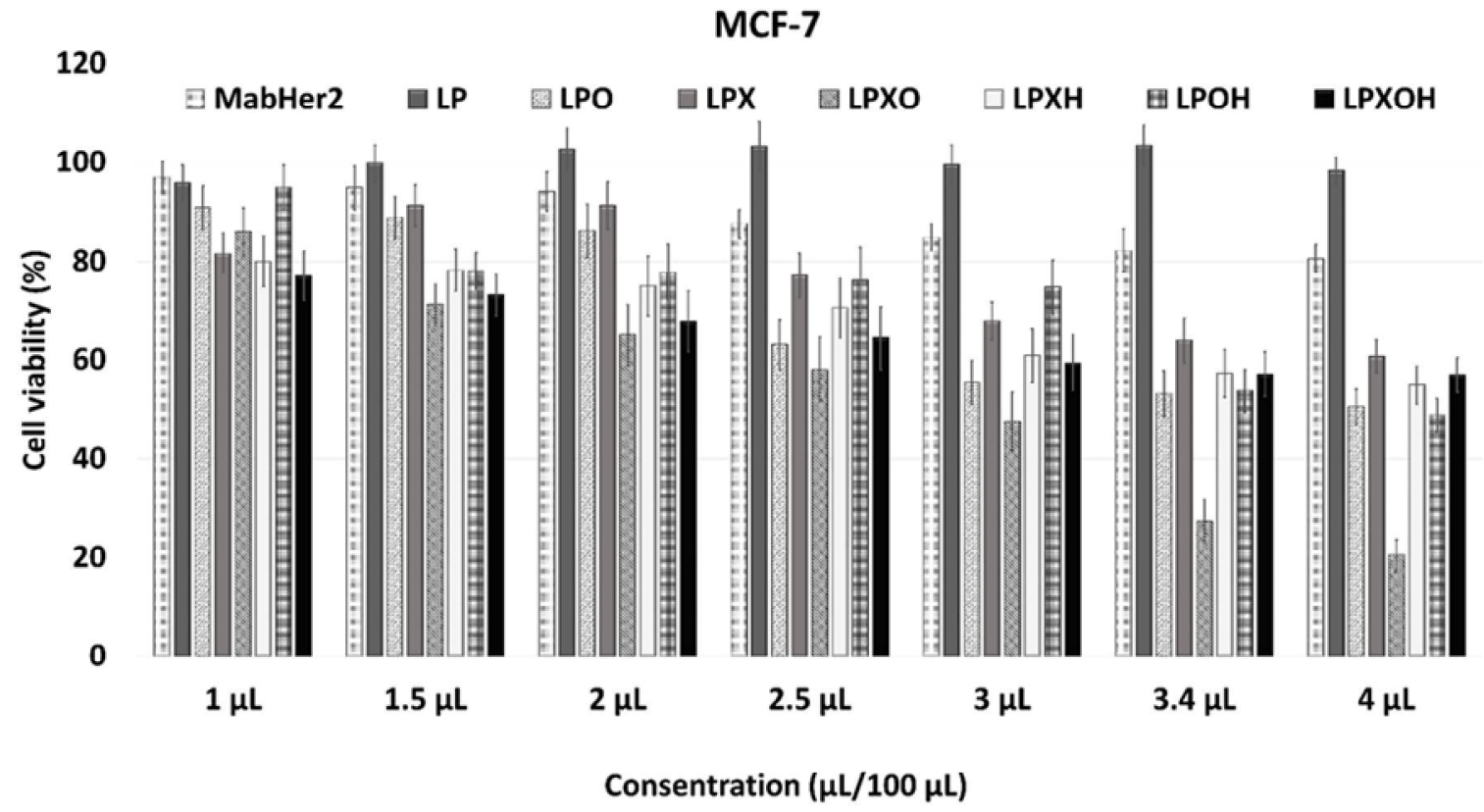

Figure 6: Viability of MCF-7 cells after being treated with MabHer2 solution and liposomes. Each condition was tested in eight replicates for $48 \mathrm{~h}$

(LPOH: 179 nm, LPXH: $189 \mathrm{~nm}$ and LPXOH: $165 \mathrm{~nm}$ ) also showed increase in size compared to LP and LPO formulations. However the sizes of these formulations remained smaller than 200 $\mathrm{nm}$.

Delivery of tumor-targeted drugs takes advantage of the fact that malignant and normal tissue differ. Passive targeting can be achieved owing to the properties of blood vessels enfolding solid tumors, such as high permeability and high retention times for active ingredients; or by using localized applications. Depending on the tumor type, the gap between endothelial connections in solid tumors is approximately 300 $\mathrm{nm}$. This gap can be used for transport of the drugs to cancer cells. This phenomenon is known as EPR (enhanced permeability and 
retention) effect. Many colloidal drug carrier systems make use of this effect, because the active ingredients stay longer in the blood circulation due to their small sizes [18]. Thus, the small particle size of the liposome-drug formulations seen in this study are consistent with EPR effect, which is desirable in cancer chemotherapy.

Positively charged liposomes electrostatically interact with cellular membranes that have net negative charges. This interaction is important for the entry the active ingredient (whether drug or genetic material)-loaded liposomes into the cell [19]. Zeta potential of LP formulation increased from $-36.90 \mathrm{mV}$ to $+31.20 \mathrm{mV}$ on addition of the cationic agent, octadecylamine. Zeta potential of the liposomes have been observed to increase with increasing amount of octadecylamine [20]. The decrease in zeta potential of $\mathrm{LPOH}$ due to addition of MabHer2 to LPO may be attributed to surface charge of MabHer2 $(+8.16 \mathrm{mV})$. This decrease is a clear evidence of the fact that MabHer2 was successfully attached onto the surface of liposome. Since LPO and MabHer2 possess positive charges, the interaction between the antibody and the liposome was most likely due to hydrogen bonding and/or hydrophobic interaction [21].

In this study, SDS-PAGE was used to determine the structural changes in antibodies. Generally, ultrasound may be used as a tool to modify the biological, chemical and physical functionalities of proteins. Sulfhydryl groups, which are essential in protein configuration and function, are affected by sonication [22]. In addition, changes in temperature, pressure and voltage during sonication influence protein activity. Therefore, applied stress conditions and their effects should be determined for each protein [23].

In this study, we tried to determine the appropriate sonication time in order to produce liposomes without negatively affecting the proteins. It was determined from the SDS-PAGE gel images that application of sonication for 20 min while keeping ultrasound power constant (20 $\mathrm{kHz}$ ) did not disrupt the protein structure (Figure 2). Since desired particle size $(<200 \mathrm{~nm})$ was achieved with sonication for $1.5 \mathrm{~min}$ at $20 \mathrm{kHz}$ power during preparation of liposomes without MabHer2, these sonication conditions were kept constant for all formulations.

In order to determine the effects of formulation conditions on MabHer2, MabHer2 was extracted from LPXH (exLPXmab) and LPXOH (exLPXOHmab) using DCM. Organic solvents increase denaturation of proteins. It has been reported that protein deactivation depends on solubility of the organic solvent in the aqueous phase; these hydrophilic organic solvents can interact with accessible hydrophobic domains of the protein and disturb its structural integrity [24]. For this reason, DCM was used considering that its low aqueous solubility ( $\mathrm{S} / \mathrm{mass}$ is $1.73 \%$ ), and retained protein $\mathrm{IgG}$ in the presence of salt (approximately $97 \%$ ) [25]. The uniformity of the SDS-PAGE gel images indicate that the antibody protein structure was not denatured by fragmentation at any point [12].

The cytotoxicity results indicate that effectiveness of MabHer2 was preserved during formulation and extraction steps, and that native MabHer2 had the same level of toxicity on MDAMD-453 cell line as exLPXmab and exLPXOHmab (Figure 4). This is proof MabHer2 did not lose its structural properties, as confirmed by the results of SDS-PAGE analysis (Figure 3).

LP formulation had no toxic effect on the cell lines. MabHer2 suspension at $2 \mu \mathrm{g} / 100 \mu \mathrm{L}$ led to $47 \%$ viability in MDA-MB-453 (HER2+) cells; but as expected, it was not toxic to MCF-7 (HER2-) cells. LPO formulation, which contained octadecylamine in order to make it cationic, was more toxic compared to LP formulation especially on MCF-7 cells; however, it did not reduce cell viability below $50 \%$.

LPX formulation showed toxicity on MDA-MD453 cells at $3.4 \mu \mathrm{L}$ concentration. On MCF-7 cells, it could not go below $50 \%$ viability even at the highest concentration. This indicates that although LPX has cationic property, it was taken up by MDA-MD-453 cells. Since LPXO formulation was loaded with PTX and carries positive charge, its entry into cells was easier; thus it was more toxic on MCF-7 cells at lower concentrations $\left(\mathrm{IC}_{50}, 3 \mu \mathrm{L} / 100 \mu \mathrm{L}\right)$. LPXH formulation did not contain cationic agent but since MabHer2 was present, it showed toxic effect on MDA-MD-453 cells at $3 \mu \mathrm{L}$, unlike the MCF-7 cells. These results indicate that antibody can be attached/sinked onto liposomes, and after release it can inhibit cell proliferation via binding to Her2 receptors on MDA-MD-453 cells.

Evaluation of $\mathrm{LPOH}$ formulation shows that it had a similar toxicity with LPO formulations. However, while LPO formulation did not show toxicity on MDA-MD-453 cells even at highest concentrations, LPOH formulation decreased viability down to $37 \%$ at $4 \mu \mathrm{L}$ concentration. This shows that antibody was loaded on the formulations and inhibited cell proliferation via acting on Her2 receptor. LPXOH formulation 
showed toxicity on MDA-MD-453 cells at $1 \mu \mathrm{L}$ concentration. When compared with the toxicity of LPXO formulation, the reduction in cell viability below $50 \%$ at lowest dose $(1 \mu \mathrm{L})$ suggests binding of LPXOH formulation to MDA-MD-453 via the antibody and increased uptake. It can also be a consequence of synergism between the ability of the antibody to inhibit cell proliferation via binding to Her2 receptor, and the toxicity of PTX. LPXO formulation was the most toxic formulation on MCF-7 cells.

However, LPXOH formulation prepared with MabHer2 was not cytotoxic. Addition of MabHer2 to LPXO formulation caused a decrease in zeta potential, and this resulted in reduced attachment ability of the particles on the cell surfaces. As a result, LPXO formulation $\left(\mathrm{IC}_{50}, 3 \mu \mathrm{L} / 100 \mu \mathrm{L}\right)$ was the most toxic formulation on MCF-7 (HER2-) cells while $\mathrm{LPXOH}$ formulation $\left(\mathrm{IC}_{50}: 1 \mu \mathrm{L} / 100\right.$ $\mu \mathrm{L}$ ) was the most toxic formulation on MDA-MD453 (HER2+) cells.

\section{CONCLUSION}

The findings of this study show that MabHer2 can be attached/linked to cationic and anionic PTX-loaded liposomes, and that PTX/MabHer2 liposomes increased toxicity in HER2 overexpressed MDA-MD-453 breast cancer cell line. Since stress conditions applied during the preparation of the systems has no adverse effect on the structure of antibodies, it is seems that an antibody attached/linked colloidal drug carrier system (provided that stability optimization is performed) can be prepared with ease and at a low cost, without the need for chemical reaction such as biotinylation or procedures for coating the surface of the particle such as pegylation.

\section{ACKNOWLEDGEMENT}

This study was supported by Anadolu University Scientific Research Foundation (Project nos. 1207S121 and 1302S028).

\section{CONFLICT OF INTEREST}

No conflict of interest associated with this work.

\section{CONTRIBUTION OF AUTHORS}

We declare that this work was done by the authors named in this article and all liabilities pertaining to claims relating to the content of this article will be borne by the authors.

\section{REFERENCES}

1. Yokoyama M. Drug targeting with nano-sized carrier systems. J Artif Organs 2005; 8: 77-84.

2. Ta TH, Dass CR, Dunstan DE. Injectable chitosan hydrogels for localised cancer therapy. $J$ Control Release. 2008; 126(3): 205-216.

3. $W u$ J, Liu $Q$, Lee RJ. A folate receptor-targeted liposomal formulation for paclitaxel. Int J Pharm.2006; 316: 148153.

4. Chang J, Wang $H$, Zhao $P$, Liang $X$, Gong $X$, Song $T$, Niu $R$. Folate-PEG coated cationic modified chitosan Cholesterol liposomes for tumor-targeted drug delivery. Biomaterials 2010; 31: 4129-4138.

5. Marcucci $F$ and Lefoulon $F$. Active targeting with particulate drug carriers in tumor therapy: fundamentals and recent progress. Drug Discov Today. 2004; 9 (5): 1359-6446.

6. Chames $P$, Regenmortel $M$, Weiss $E$ and Baty $D$. Themed Section: Vector Design And Drug Delivery Review Therapeutic antibodies: successes, limitations and hopes for the future. Br J Pharmacol. 2009; 157: 220-233.

7. Yang $X$, Jia $X$, Corvalan J RF, Wang $P$, Davis CG. Development of $A B X-E G F$, a fully human anti-EGF receptor monoclonal antibody, for cancer therapy. Crit Rev Oncol Hemat.2001; 38: 17-23.

8. Elbayoumi TA, Torchilin VP. Enhanced cytotoxicity of monoclonal anticancer antibody 2C5-modified doxorubicin-loaded PEGylated liposomes against various tumor cell lines. Eur J Pharm Sci. 2007; 3(2): 159-168.

9. Slamon DJ, Leyland-Jones $B$, Shak $S$, Fuchs $H$, Paton V, Bajamonde $A$, et al. Use of chemotherapy plus a monoclonal antibody against HER2 for metastatic breast cancer that overexpresses HER2. N Engl J Med. 2001; 344(11): 783-92.

10. Hermanson GT. Liposome Conjugates and Derivatives. Bioconjugate Techniques. 3rd ed. Academic Press; Elsevier Inc; 2013. 2nd EACR Special Conference on Cell Death in Cancer [homepage on the Internet].

11. Buyukkoroglu G, Gezgin S. Targetting of liposomal system with anti-her2 antibody. Proceedings Book; 45p. [cited 30 Jan 2014]. Available from: http://www.eacr.org/celldeath2014.

12. Sadeghi AA, Nikkhah A, Shawrang P, Shahrebabak MM. Protein degradation kinetics of untreated and treated soybean meal using SDS-PAGE. Anim Feed Sci Tech. 2006; 126 (1-2): 121-133.

13. Ekambaram $P$, Sathali $A H$ and Priyanka K. Solid lipid nanoparticles: A review. Sci Revs Chem Commun. 2012; 2(1): 80-102.

14. Jin C, Ba, L, Wu H, Tian F, Guo G. Radiosensitization of paclitaxel, etanidazole and paclitaxel+etanidazole nanoparticles on hypoxic human tumor cells in vitro. Biomaterials. 2007; 28: 3724-3730.

15. Gencer $S$, Cebeci A, Irmak-Yazicioglu MB. Silencing of the MMP-3 Gene by siRNA Transfection in Gastric

Trop J Pharm Res, May 2016; 15(5): 902 
Cancer AGS Cells. J Gastrointestin Liver Dis 2010; 20 (1): 19-26.

16. Radomska-Soukharev A. Stability of lipid excipients in solid lipid nanoparticles. Adv Drug Delivery Rev. 2007; 59: 411-418.

17. Mehnert W, Mäder K. Solid lipid nanoparticles: Production, characterization and applications. Adv Drug Deliver Rev. 2001; 47(2-3): 165-196.

18. Maeda H, Bharate GY, Daruwalla J. Polymeric drugs for efficient tumor-targeted drug delivery based on EPReffect. Eur J Pharm Biopharm. 2009; 71: 409-419.

19. Tros de llarduya $C$, Sunb $Y$, Düzgüneş N. Gene delivery by lipoplexes and polyplexes. Eur. J. Pharma. Sci. 2010; 40: 159-170.

20. Şenel B, Büyükköroğlu G, Yazan Y. Solid lipid and chitosan particulate systems for delivery of siRNA. Pharmazie. 2015; 8: 698-705.
21. Lee AL, Wang $Y$, Cheng HY, Pervaiz S, Yang YY. The co-delivery of paclitaxel and Herceptin using cationic micellar nanoparticles. Biomaterials. 2009; 30: 919-927.

22. Singh, H, MacRitchie, F. Use of Sonication to Probe Wheat Gluten Structure. Cereal Chem 2001; 78: 526529.

23. Bo L, Kaustav M, Shengwen S, Jianping W. Effect of sonication on thermolysin hydrolysis of ovotransferrin. Food Chemistry. 2011; 124: 808-815.

24. Pe'rez-Rodriguez C, Montano N, Gonzalez K, Griebenow $K$. Stabilization of $\alpha$-chymotrypsin at the $\mathrm{CH} 2 \mathrm{Cl} / 2 /$ water interface and upon water-in-oil-in-water encapsulation in PLGA microspheres. J Control Release. 2003; 89(1): 71-75

25. Mart'ınez-Arag'on M, Burghoff S, Goetheer ELV, Haanc $A B$. Guidelines for solvent selection for carrier mediated extraction of proteins. Sep Purif Technol. 2009; 65(1): 65-72. 